\title{
Electrochemical cell design for the impedance studies of chlorine evolution at DSA ${ }^{\circledR}$ anodes
}

J. F. Silva, A. C. Dias, P. Araújo, C. M. A. Brett, and A. Mendes'

Citation: Review of Scientific Instruments 87, 085113 (2016); doi: 10.1063/1.4959097

View online: http://dx.doi.org/10.1063/1.4959097

View Table of Contents: http://aip.scitation.org/toc/rsi/87/8

Published by the American Institute of Physics

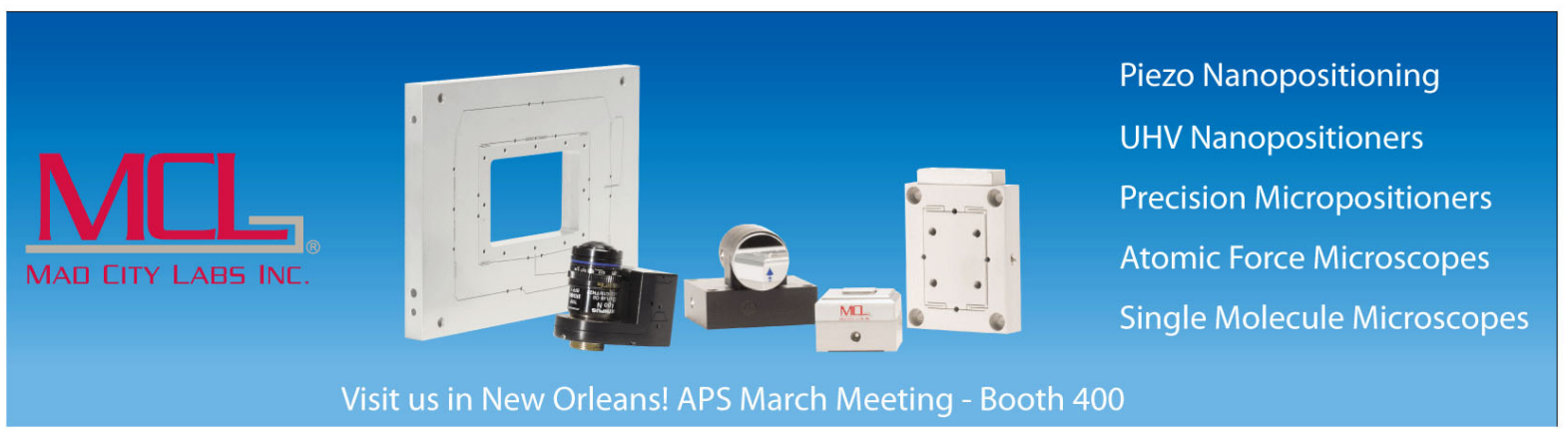




\title{
Electrochemical cell design for the impedance studies of chlorine evolution at $D S A^{\circledR}$ anodes
}

\author{
J. F. Silva, ${ }^{1,2}$ A. C. Dias, ${ }^{1}$ P. Araújo, ${ }^{1}$ C. M. A. Brett,${ }^{3}$ and A. Mendes ${ }^{2, a)}$ \\ ${ }^{1}$ CUF-Químicos Industriais, S.A., Quinta da Indústria, 3860-680 Estarreja, Portugal \\ ${ }^{2}$ LEPABE, Faculdade de Engenharia, Universidade do Porto, Rua Dr. Roberto Frias s $/ \mathrm{n}$, \\ 4200-465 Porto, Portugal \\ ${ }^{3}$ Department of Chemistry, Faculty of Sciences and Technology, University of Coimbra, Rua Larga, \\ 3004-535 Coimbra, Portugal
}

(Received 28 November 2015; accepted 7 July 2016; published online 15 August 2016)

\begin{abstract}
A new electrochemical cell design suitable for the electrochemical impedance spectroscopy (EIS) studies of chlorine evolution on Dimensionally Stable Anodes (DSA ${ }^{\circledR}$ ) has been developed. Despite being considered a powerful tool, EIS has rarely been used to study the kinetics of chlorine evolution at DSA anodes. Cell designs in the open literature are unsuitable for the EIS analysis at high DSA anode current densities for chlorine evolution because they allow gas accumulation at the electrode surface. Using the new cell, the impedance spectra of the DSA anode during chlorine evolution at high sodium chloride concentration ( $5 \mathrm{~mol} \mathrm{dm}^{-3} \mathrm{NaCl}$ ) and high current densities (up to $140 \mathrm{~mA} \mathrm{~cm}^{-2}$ ) were recorded. Additionally, polarization curves and voltammograms were obtained showing little or no noise. EIS and polarization curves evidence the role of the adsorption step in the chlorine evolution reaction, compatible with the Volmer-Heyrovsky and Volmer-Tafel mechanisms. Published by AIP Publishing. [http://dx.doi.org/10.1063/1.4959097]
\end{abstract}

\section{INTRODUCTION}

The chlor-alkali industry is one of the most important worldwide commodity industries and it underpins about $60 \%$ of the chemical industry turnover. ${ }^{1}$ Indeed, the broad range of uses of both sodium hydroxide and chlorine in industry (e.g., pharmaceutical or fertilizer industries) and for consumers as disinfectant or detergents places them among the top 10 chemicals. ${ }^{2}$ The electrochemical route is almost the only one to produce chlorine and sodium hydroxide, representing more than $95 \%$ of the chlorine and $99.5 \%$ of the sodium hydroxide total worldwide production. ${ }^{2}$ Three electrochemical cell technologies are well established for producing chlorine and sodium hydroxide-mercury, diaphragm, and membrane cells. ${ }^{2,3}$ However, due to the economic and environmental issues, mercury and diaphragm cells have been replaced and almost all new plants are equipped with membrane cells. ${ }^{3,4}$ In a membrane cell, the anode and the cathode compartments are separated by a cation exchange membrane. At the cathode, a nickel plate, hydrogen, and hydroxide ions are produced by the water reduction. At the anode, a DSA ${ }^{\circledR}$ (dimensionally stable anode), chloride is oxidized to chlorine. Sodium ions are transported through the cation exchange membrane from anode to cathode compartment. Water reduction and chloride oxidation are the main electrochemical reactions; however, undesired reactions also occur. The most critical undesired reaction occurs at the anode and consists in oxygen evolution via water oxidation. This reaction affects not only the purity of the products and the efficiency of

\footnotetext{
a) Author to whom correspondence should be addressed. Electronic mail: mendes@fe.up.pt. Tel.: +351225081 695. Fax: + 351225081449.
}

the process, but is also responsible for the fast aging of the anode. $^{2}$

Several mechanisms have been proposed for chlorine evolution at DSA anodes. ${ }^{2,5,6}$ Often the mechanism proposed relies on electrochemical analysis, i.e., the Tafel slope, potential decay curves, and cyclic voltammetry; ${ }^{7-10}$ however, electrochemical impedance spectroscopy (EIS) has rarely been reported for this purpose. EIS has been employed in kinetic studies of chlorine evolution on platinum ${ }^{11-13}$ but not on DSA electrodes. It has been used to characterize DSA anodes in low concentration chloride solutions ${ }^{14-21}$ at low potentials, $1.05 \mathrm{~V}$ vs $\mathrm{Ag} / \mathrm{AgCl}$ to $1.18 \mathrm{~V}$ vs $\mathrm{Ag} / \mathrm{AgCl},{ }^{22,23}$ which corresponds to current densities up to $10 \mathrm{~mA} \mathrm{~cm}{ }^{-2}$. These conditions are far from those used industrially for producing chlorine, where the current densities reach $400 \mathrm{~mA} \mathrm{~cm}^{-2}$.

EIS analysis is only possible if stable impedance spectra can be obtained and these depend on the cell design. Since EIS is so important for studying electrochemical systems, this article describes an electrochemical cell design suitable for operating at high current densities, in order to permit the study of chlorine evolution under typical industrial operating conditions.

The most common configuration of an electrochemical cell consists of three vertically placed electrodes. Due to its flexibility, reduced cost, and easy operation, it is one of the most used cell designs in electrochemical experiments. ${ }^{24}$ More complex cells have been used for specific purposes. ${ }^{25-30}$ An extensive literature survey of electrochemical cell designs equipped with three electrodes is available in the work of Zoski ${ }^{31}$ and Kissinger and Heineman, ${ }^{24}$ which provide general guidelines about cell design. Due to the specificity of each investigation, most authors build their own cells, but do not describe the cell used. ${ }^{11,14,15,21,32}$ 
Different cell designs have been made in order to accommodate specially shaped electrodes ${ }^{26}$ or to meet restrictions regarding electrode exposure to the electrolyte. ${ }^{33}$ For instance, for testing electrodes for which only one face is allowed to contact the electrolyte, the rest is protected by a Teflon holder ${ }^{23,34}$ or with inert components such as epoxy resins. ${ }^{35}$ An alternative approach is to machine a hole in one cell wall so that the electrode surface is flushed with the internal cell body wall. In this type of cell, only the front face of the electrode is accessible to electrolyte; it must be ensured that the electrode is sufficiently tightly fitted to prevent infiltration of solution between the electrode and the cell body. This type of cell has been used in previous work for studying gas evolution reactions. ${ }^{36}$ An additional advantage of this design is the easy electrical connection to the working electrode, on the back face of the DSA. In this way, no other metal can contact the electrolyte, which avoids the occurrence of side reactions.

Torcheux et al. ${ }^{33}$ report a similar cell configuration but with an O-ring placed between the electrode surface and the back of the cell wall. The O-ring seals the electrode surroundings, although it creates a gap between the electrode surface and the wall surface. In this design, gas bubbles can accumulate over the electrode. The formation of bubbles at gas-evolving electrodes has already been indicated as a critical point in mechanistic studies. ${ }^{37}$ The bubbles have sometimes been associated with positive effects due to the improvement of mass transfer, ${ }^{38}$ but more often have been identified as an inconvenience since bubbles create additional ohmic resistance and blockage of the electrode surface. ${ }^{23}$ Moreover, the accumulation of gases on the electrode, which can vary as a function of time, makes the current fluctuate and EIS analysis impossible to perform. ${ }^{39,40}$

A horizontal orientation with the electrode facing upwards facilitates bubble rise through the electrolyte solution and avoids bubble coalescence at the electrode surface. The horizontal orientation has been demonstrated to improve the mass transfer of hydrogen and oxygen produced electrochemically. ${ }^{38,41}$ Despite not being the standard approach, a horizontal orientation with the electrode facing upwards was already used by previous authors, such as Ovarfort, ${ }^{42}$ Bertagna et al.,${ }^{43}$ Hendricks et al., ${ }^{44}$ and Wozniak et al.,${ }^{26}$ for studying other electrode processes. Ovarfort ${ }^{42}$ describes the Avesta electrochemical cell for pitting corrosion tests; this cell, suited for low current density experiments, was a landmark in the corrosion field. To our knowledge, studies regarding chlorine mass transfer in this configuration have not yet been carried out.

Using the horizontal orientation, an O-ring can seal the electrode/cell body junction without interfering with gas release and is also an effective tool to define the electrode area, as reported by Wozniak et al. ${ }^{26}$ In order to prevent infiltration, the electrode plus O-ring must be pressed onto the underside of the cell. Some authors accomplish this by tightening screws with bolts or screw directly into the cell body. ${ }^{43-45}$ More complex pressing systems were used by Bowler et al. ${ }^{46}$ and Wozniak et al.: ${ }^{26}$ while the former used a spring, the latter used two half-turn thumbscrews.
In the present work, the effectiveness of the liquid sealing is ensured by a single large Plexiglas ${ }^{\circledR}$ screw thread.

Previous designs were shown not to be reliable to study chlorine evolution on DSA anodes because they either do not prevent infiltration or do not permit electrochemical characterization of the electrode. To meet both requirements, a new cell with the electrode placed at the bottom together with the mechanical stirring of the electrolyte solution was designed. Mechanical stirring was shown to be the only approach that ensures the homogeneity of the electrolyte solution and creates enough shear strength to remove the evolved gas bubbles and allow reaction over the whole electrode surface. In these conditions, accurate electrochemical characterization was achieved.

Although the electrode configuration used in industrial electrochemical plants is different, the convection and the operating current range of the new cell make it a useful approach to mimic the industrial process and obtain mechanistic information. The synergetic effect of electrode orientation and vertical stirring permits electrochemical impedance measurements at $60^{\circ} \mathrm{C}$ using a $5 \mathrm{~mol} \mathrm{dm}^{-3} \mathrm{NaCl}$ aqueous solution, even at current densities as high as $150 \mathrm{~mA} \mathrm{~cm}$. These values are close to the industrial current range which is around $300-400 \mathrm{~mA} \mathrm{~cm}^{-2}$.

The good performance of this new cell was verified by recording polarization curves, cyclic voltammetry, and electrochemical impedance spectroscopy.

\section{CELL DESIGN}

The designed electrochemical cell is shown in Figure 1 and consists of a $400 \mathrm{ml}$ jacketed cylindrical cell made of Plexiglas with a Plexiglas lid. Heated water from a water circulation bath is pumped through the jacket to control the temperature of the electrolyte solution in the cell. A $16 \mathrm{~mm}$ diameter hole was drilled through the cell bottom to give access to the working electrode (DSA anode), which was placed $2 \mathrm{~mm}$ below the bottom of the main compartment inside a cylindrical cavity of $20 \mathrm{~mm}$ diameter and $5 \mathrm{~mm}$ depth. The working electrode is a round plate of $20 \mathrm{~mm}$ diameter and $3 \mathrm{~mm}$ thickness sealed to the cell with a $16 \mathrm{~mm}$ internal diameter and a $2 \mathrm{~mm}$ thick Viton O-ring. A $20 \mathrm{~mm}$ copper collector disk welded to a copper wire was pressed onto the electrode back surface to ensure good electrical connection to the DSA electrode. The sealing of the electrode with O-ring plus copper disk is ensured by pressing it into the cell body with a single large Plexiglas screw. Besides the ability to change the electrode quickly and easily, the adjustable screw allows accommodating electrodes of different thicknesses.

Homogenization of the electrolyte and cleaning of the bubbles formed on the electrode surface, in order to guarantee a stable electrochemical behavior, are accomplished using a mechanical stirrer.

The cell lid is $10 \mathrm{~mm}$ thick and is drilled in order to accommodate the shaft of the mechanical stirrer, the counter electrode, the reference electrode, and a thermometer. An extra hole was made that allows sparging an inert gas in the 
$\mathbf{a}$

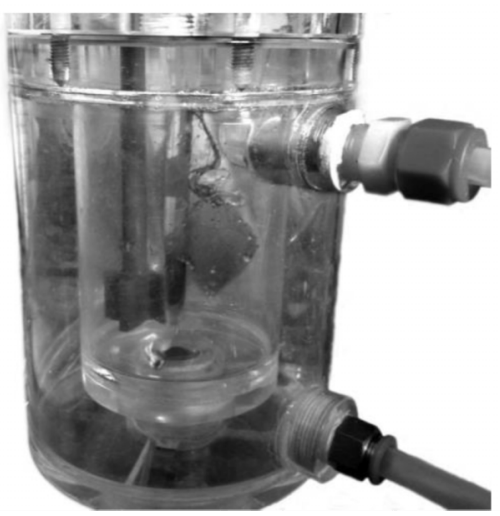

b

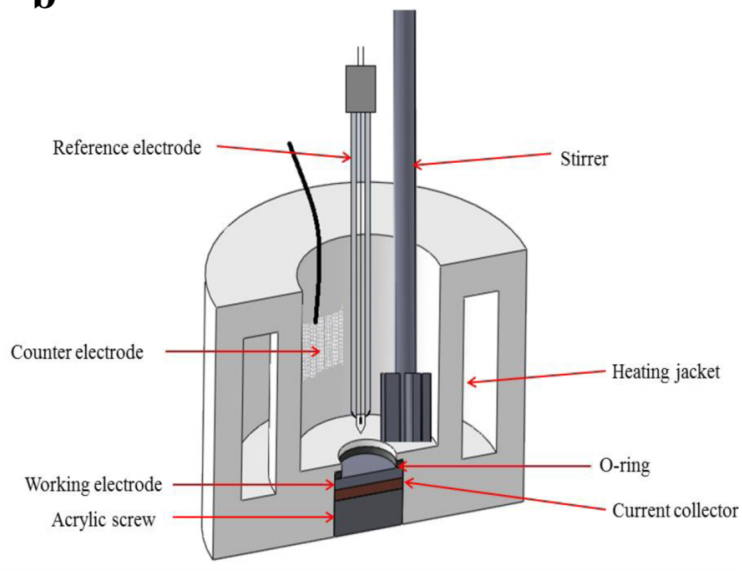

FIG. 1. The new electrochemical cell. (a) Photo and (b) schematic cross section.

electrolyte. The reference electrode is placed at the centre of the lid in order to be aligned with the working electrode at the bottom of the cell. The counter electrode, a platinum mesh plus platinum wire connector, is placed vertically at the mid-point between the reference electrode and the cell wall. The counter electrode external connection to the potentiostat was done using a gold-coated crocodile clip in order to be more resistant to chlorine corrosion. A PVC stirrer, which is compatible with the solution of sodium chloride and chorine, was fabricated to ensure adequate stirring of the cell electrolyte solution. The stirrer position was carefully chosen to enhance the gas bubble rising with minimum impact on the electrochemical measurements.

The body of the cell includes two side accesses designed to continuously feed electrolyte if desired. The access heights were carefully chosen in order to control the electrolyte level inside the cell.

\section{EXPERIMENTAL}

\section{A. Reagents}

Sodium chloride solutions were prepared from $5 \mathrm{~mol}$ $\mathrm{dm}^{-3} \mathrm{NaCl}$ solutions. The initial $\mathrm{pH}$ was set to 2 using industrial grade $\mathrm{HCl} 33$ wt. \%. Both solutions were supplied by CUF-QI (Portugal). When necessary, the initial solution was diluted using deionised water (Millipore, resistivity $\geq 18 \mathrm{M} \Omega \mathrm{cm}$ ).

\section{B. Electrodes}

The working electrode was a part of a DSA anode made of titanium coated with $\mathrm{RuO}_{2}-\mathrm{IrO}_{2}-\mathrm{TiO}_{2}$ supplied by electrocell. The exposed area was $2.0 \mathrm{~cm}^{2}$. A platinum mesh was used as a counter electrode. $\mathrm{An} \mathrm{Ag} / \mathrm{AgCl}$ electrode saturated with $\mathrm{KCl}$ was used as a reference electrode.

\section{Electrochemical measurements}

Polarization curves, cyclic voltammetry, and electrochemical impedance spectroscopy (EIS) measurements were performed to characterize the cell. Polarization curves and cyclic voltammograms were recorded using a Gamry 600 potentiostat.

Cyclic voltammetry experiments were run at $20^{\circ} \mathrm{C}$, between $0.0 \mathrm{~V}$ vs $\mathrm{Ag} / \mathrm{AgCl}$ and $+1.2 \mathrm{~V}$ vs $\mathrm{Ag} / \mathrm{AgCl}$, covering the capacitive/pseudocapacitive region of the electrode as well as the beginning of the chlorine/oxygen evolution region. Ten potential cycles were performed at a scan rate of $50 \mathrm{mV} \mathrm{s}^{-1}$.

Three replicas of each polarization curve were recorded at $1 \mathrm{mV} \mathrm{s}^{-1}$ scan rate in the potential range between $+1.0 \mathrm{~V}$ and $+1.4 \mathrm{~V}$ vs $\mathrm{Ag} / \mathrm{AgCl}$, at $60^{\circ} \mathrm{C}$ and $80^{\circ} \mathrm{C}$. The contribution of ohmic resistance, obtained from analysis of the impedance spectra, was subtracted from the polarization curves.

EIS measurements were performed using a PC-controlled Solartron 1250 Frequency Analyzer, coupled to a Solartron 1286 Electrochemical Interface controlled by ZPlot 2.4 software. The impedance spectra were obtained in potentiostatic mode with a $10 \mathrm{mV}$ rms amplitude perturbation in the frequency range from $65 \mathrm{kHz}$ to $1 \mathrm{~Hz}, 10$ data points per frequency decade, with auto-integration set as long and a maximum integration time of $100 \mathrm{~s}$. Two replicas of each impedance spectrum were recorded at $+1.20 \mathrm{~V},+1.25 \mathrm{~V},+1.30 \mathrm{~V},+1.35 \mathrm{~V}$, and $+1.40 \mathrm{~V}$ vs $\mathrm{Ag} / \mathrm{AgCl}$ at $60^{\circ} \mathrm{C}$. These potentials are in the oxygen and chlorine evolution potential region.

The solution in the cell was stirred at $500 \mathrm{rpm}$ during polarization curve recording and EIS measurements. $\mathrm{pH}$ measurements were made with a CRISON 2001 micro$\mathrm{pH}$-meter. Experiments were carried out in the temperature range of $20^{\circ} \mathrm{C}-80^{\circ} \mathrm{C} \pm 2{ }^{\circ} \mathrm{C}$. The temperature in the cell was controlled using a HUBER CC1 water circulation bath.

\section{RESULTS}

\section{A. Effect of stirring}

A first set of experiments was carried out to assess the performance of the new electrochemical cell for studying chlorine evolution. Without stirring, accumulation and coalescence of bubbles on the anode surface take place. 
$\mathbf{a}$

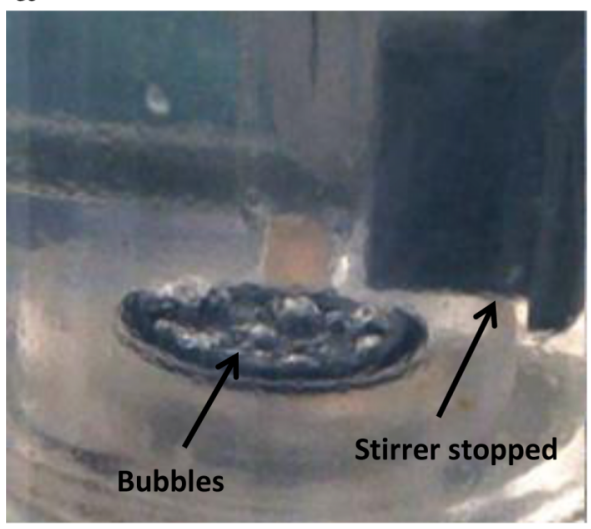

b

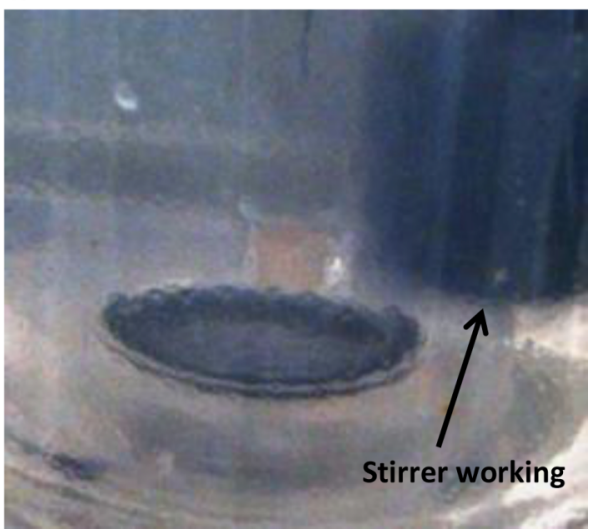

FIG. 2. Detail of the anode surface during chlorine evolution at $1.30 \mathrm{~V}$ vs $\mathrm{Ag} / \mathrm{AgCl}$ in 5 mol $\mathrm{dm}^{-3} \mathrm{NaCl}, \mathrm{pH} 2, T=60{ }^{\circ} \mathrm{C}$; (a) no stirring; (b) electrolyte stirred at $500 \mathrm{rpm}$. Legend was added to highlight the stirring effect.

These phenomena are illustrated in Figure 2(a). Conversely, Figure 2(b) shows an electrode surface free of gas bubbles. This was achieved by using a mechanical stirrer at $500 \mathrm{rpm}$. The corresponding impedance spectra are shown in Figure 3; the plots join consecutive points to illustrate the sequence of acquired data.

Figure 3(a) illustrates the random changes in the impedance values in the spectrum related to the formation and the release of bubbles from the electrode, when there is no stirring. A bubble on the electrode surface decreases the available active area for ionic transport and thence the measured interfacial resistance, and the presence of a reaction product adjacent to the electrode makes the oxidation overpotential increase. In the present case, when a bubble is released, a marked change in the impedance signal is seen due to the increase in electrode area and consequent lower impedance value; in Figure 3(b), the instants preceding bubble release can be identified. Similar fluctuations are often observed in spectra recorded in the potential range in which the chlorine evolution reaction occurs and are more common at higher current densities. As soon as the stirrer was switched on, the fluctuations in impedance stopped, as illustrated in Figure 3(b). This spectrum clearly illustrates the benefit of this new cell design.

\section{B. Polarization curves}

Polarization curves were recorded at $60{ }^{\circ} \mathrm{C}$ and $80^{\circ} \mathrm{C}$ as described in Sec. III. The working electrode potential was plotted against the logarithm of the current density. Figure 4 shows polarization curves at both temperatures, as well as two reference lines representing the $40 \mathrm{mV}$ decade $^{-1}$ slope. The potential range depicted was chosen to include only positive, anodic currents within and close to the Tafel region. The potentials were corrected for ohmic resistance obtained from EIS analysis: $1.56 \Omega \mathrm{cm}^{2}$ at $60^{\circ} \mathrm{C}$ and $1.26 \Omega \mathrm{cm}^{2}$ at $80^{\circ} \mathrm{C}$. Thus, the potential range presented in Figure 4 corresponds to the original potential range $(+1.0$ to $+1.4 \mathrm{~V}$ $\mathrm{vs} \mathrm{Ag} / \mathrm{AgCl}$ ) corrected for the potential corresponding to the ohmic contribution.

The anodic polarization curves shown in Figure 4 agree with the previous work by other authors. ${ }^{8,47}$ Three distinct zones are identified in these curves. The first zone is from low potentials up to ca. $+1.07 \mathrm{~V}$ vs $\mathrm{Ag} / \mathrm{AgCl}$; the second $\mathbf{a}$

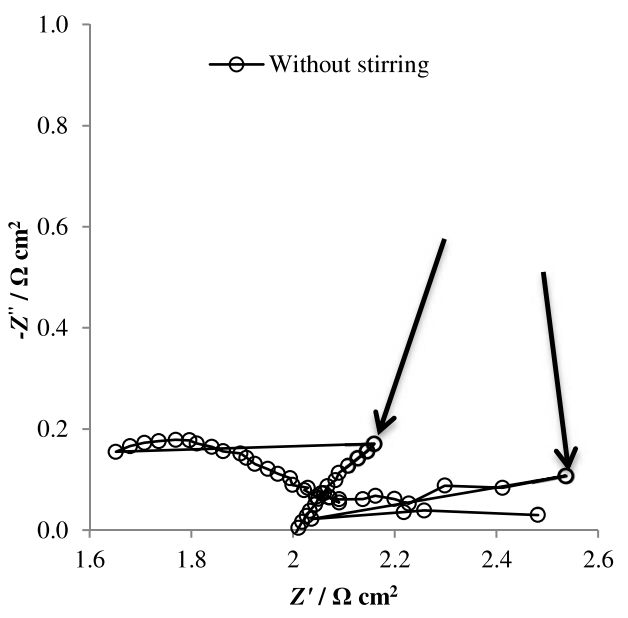

b

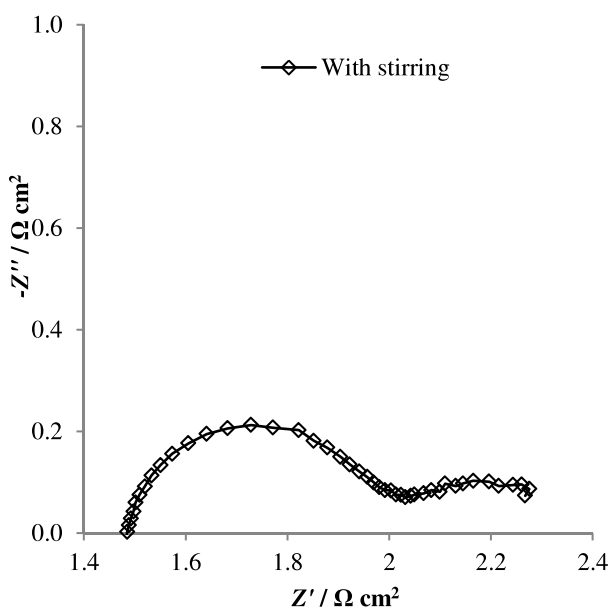

FIG. 3. Effect of stirring on complex plane impedance spectra of DSA anode in $5 \mathrm{~mol} \mathrm{dm}^{-3} \mathrm{NaCl}, \mathrm{pH} 2$ at $60^{\circ} \mathrm{C}$. (a) No stirring; (b) electrolyte stirred at $500 \mathrm{rpm}$. Arrows identify the points preceding the bubble release. 


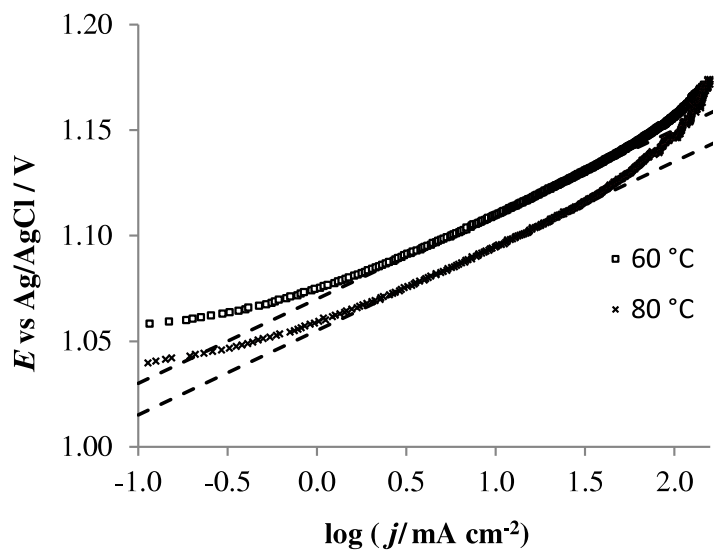

FIG. 4. Polarization curves for DSA anode in $5 \mathrm{~mol} \mathrm{dm}^{-3} \mathrm{NaCl}, \mathrm{pH} 2$ at $60^{\circ} \mathrm{C}$ and $80^{\circ} \mathrm{C}$; scan rate $1 \mathrm{mV} \mathrm{s}^{-1}$ in the positive direction.

zone is from +1.07 up to $+1.14 \mathrm{vs} \mathrm{Ag} / \mathrm{AgCl}$; the last is from $+1.14 \mathrm{vs} \mathrm{Ag} / \mathrm{AgCl}$ upwards. The first region corresponds to potentials where both anodic and cathodic reactions occur. In the second zone, cathodic currents become negligible and the potential vs logarithmic current density can be described by the Tafel equation. In the third zone, the overpotential no longer follows Tafel behavior; its shape suggests a VolmerTafel mechanism with recombination (Tafel) as a ratedetermining step. ${ }^{13}$

The Tafel slopes found in the intermediate region, $43.1 \pm 0.6 \mathrm{mV} \mathrm{decade}{ }^{-1}$ at $60^{\circ} \mathrm{C}$ and $40.8 \pm 0.8 \mathrm{mV} \mathrm{\text {decade } ^ { - 1 }}$ at $80^{\circ} \mathrm{C}$, are similar to those reported in the literature, ca. $40 \mathrm{mV}$ decade $^{-1}$ in the temperature range $25-90{ }^{\circ} \mathrm{C}^{7,23,48}$ These values are in agreement with the Volmer-Heyrovsky mechanism considering electrochemical desorption of chlorine as the rate-limiting step. ${ }^{7,23,48}$ From this mechanism, the charge transfer coefficients, $\alpha$, were found to be 0.54 at $60^{\circ} \mathrm{C}$ and 0.71 at $80^{\circ} \mathrm{C}$. These values are between 0.5 and 1.0 , which have been reported in the literature as the limiting cases of a symmetric oxidation-reduction activation barrier and a barrierless or quasibarrierless reaction, respectively. ${ }^{8,9}$

\section{Cyclic voltammetry}

Figure 5(a) shows cyclic voltammograms obtained at different scan rates in $0.5 \mathrm{~mol} \mathrm{dm}^{-3} \mathrm{NaCl}$. The voltammo- grams present the typical shape seen in previous reports concerning the study of titanium plates coated with the ternary oxide $-\mathrm{IrO}_{2}-\mathrm{TiO}_{2}-\mathrm{RuO}_{2} \cdot{ }^{20,21,49}$

The current density behavior observed in the cyclic voltammograms results from the contribution of the capacitive current associated with the double layer, as well as the pseudocapacitance related to redox transitions of the iridium and ruthenium oxides present in the oxide coating. ${ }^{17,18}$ Pseudocapacitive currents are seen in the potential range $+0.3 \mathrm{~V}$ to $+0.9 \mathrm{~V}$ and are especially noticeable at higher scan rates. The pseudocapacitive behavior arises from the injection/ejection of protons that occurs at the noble metalelectrolyte interface and can be generically described as follows: $:^{17,18}$

$$
\mathrm{MO}_{x}(\mathrm{OH})_{y}+\delta \mathrm{H}^{+}+\delta \mathrm{e}^{-} \rightleftharpoons \mathrm{MO}_{x-\delta}(\mathrm{OH})_{y+\delta},
$$

where $\mathrm{M}$ is the noble metal in the DSA anode, the noble metals being iridium and ruthenium.

At the upper potential limit, around $+1.20 \mathrm{~V}$ vs $\mathrm{Ag} / \mathrm{AgCl}$, the onset of chlorine evolution is seen in the positive sweep, while in the negative sweep, chloride desorption can be identified by a slight deviation from the baseline. This feature is more noticeable at low scan rates since at higher scan rates the capacitive current densities overlap the desorption currents.

More detailed analysis of Figure 5(a) was done by plotting the anodic peak current density as a function of the square root of the scan rate, Figure 5(b), which shows the linear dependence of the anodic peak current density on the square root of the scan rate, indicating a diffusion-controlled process. $^{50}$

\section{Electrochemical impedance spectroscopy}

Figure 6(a) shows complex plane spectra obtained for a DSA anode at different potentials in the range $65 \mathrm{kHz}-0.1 \mathrm{~Hz}$ in $5 \mathrm{~mol} \mathrm{dm}^{-3} \mathrm{NaCl}$. The current densities range from $40.3 \mathrm{~mA} \mathrm{~cm}-2$ at $1.20 \mathrm{~V}$ vs $\mathrm{Ag} / \mathrm{AgCl}$ to $140 \mathrm{~mA} \mathrm{~cm}{ }^{-2}$ at $1.40 \mathrm{~V}$ vs $\mathrm{Ag} / \mathrm{AgCl}$; the ohmic resistance has been subtracted for clarity. The corresponding Bode diagrams are shown in Figure 6(b). The impedance values for the lowest frequencies at the potentials 1.35 and $1.40 \mathrm{~V}$ are not displayed since they

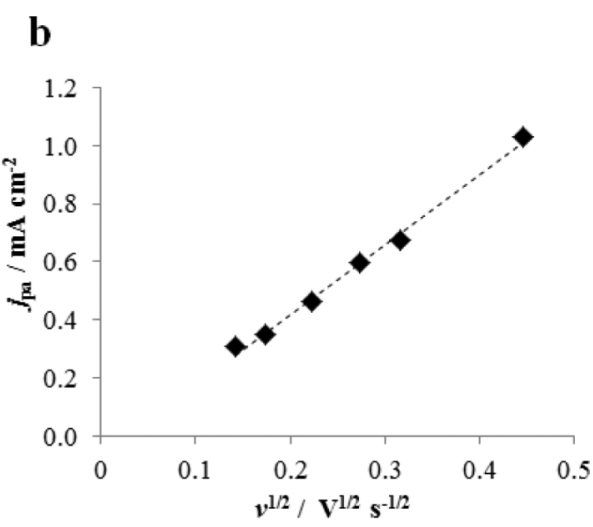

FIG. 5. (a) Cyclic voltammograms of DSA anode as a function of scan rate in $0.5 \mathrm{~mol} \mathrm{dm}-3 \mathrm{NaCl}, \mathrm{pH} 2$ at $20^{\circ} \mathrm{C}$. (b) Plot of anodic peak current density, $j_{\text {pa }}$, vs. scan rate. 
a

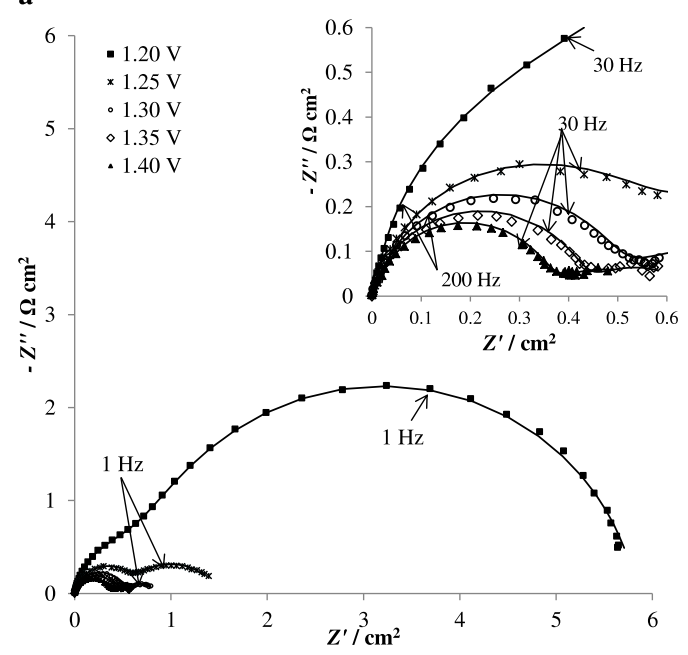

b

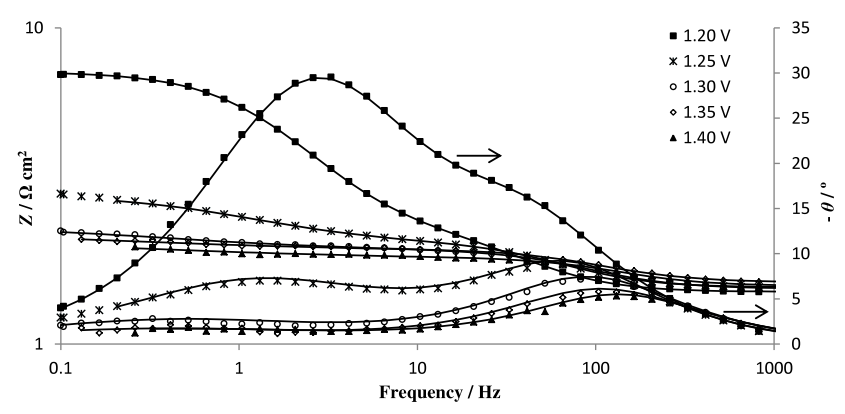

FIG. 6. (a) Complex plane spectra for a DSA electrode in $5 \mathrm{~mol} \mathrm{dm}^{-3} \mathrm{NaCl}$, $\mathrm{pH} 2$ at $60^{\circ} \mathrm{C}$ at different potentials. Inset shows the high frequency part of the spectra. Lines show equivalent circuit fitting. (b) Bode diagrams of the spectra in (a). Lines show equivalent circuit fitting.

showed significant dispersion due to the increasing rate of chlorine evolution.

Figure 6(a) shows a well-defined high-frequency semicircle for each spectrum. A low-frequency semicircle is only well defined at lower potentials. Spectra showing two semicircles have often been obtained for DSA electrodes in sodium chloride solutions. ${ }^{19-21,32}$ These authors attribute the high frequency semicircle to the resistance and the capacitance of the coating while the semicircle at lower frequencies is assigned to the capacitance of the double layer, $C_{\mathrm{dl}}$ and the charge transfer resistance, $R_{\mathrm{ct}}$. In the present work, both semicircles should represent faradaic processes since the diameter of both semicircles decreases with an increase in potential. According to Hoseinieh and coworkers $^{21}$ and Ye and co-workers, ${ }^{32}$ the semicircle related to the coating should be independent of the potential. Therefore, the electrical equivalent circuit (EEC) used in the present work is shown in Figure 7.

This EEC includes elements to represent the pseudocapacitance, $C_{\mathrm{p}}$, and the coupled resistance, $R_{\mathrm{p}}$, which are assigned to the adsorption/desorption of chloride intermediates that precede the chlorine formation; $R_{\Omega}$ is the ohmic cell resistance. The EEC in Figure 7 was already used to fit the impedance of the chlorine evolution reaction on platinum electrodes. ${ }^{11,12}$ The charge transfer resistance should be related to chlorine evolution on the DSA anode. Despite

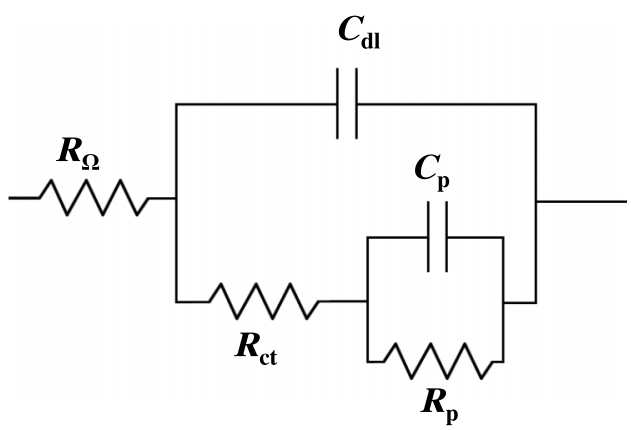

FIG. 7. Equivalent electrical circuit used to fit the impedance spectra.

the thermodynamic potential for oxygen evolution being $1.03 \mathrm{~V}$ vs $\mathrm{Ag} / \mathrm{AgCl}$ and for chlorine $1.16 \mathrm{~V}$ vs $\mathrm{Ag} / \mathrm{AgCl}$, the coating composition, which is designed for chlorine evolution, makes the oxygen kinetics sluggish. Thus, at the potentials used in the EIS measurements, oxygen evolution should be negligible compared to the chlorine evolution. ${ }^{2}$

The double layer capacitance and the pseudocapacitance were fitted to constant phase elements (CPEs) instead of ideal capacitors, the necessity arising from the non-uniform nature of both the electrode-solution interface and the coating, and manifested in the depressed semicircles. CPE have often been used to fit the impedance of DSA anodes due to the roughness and porosity of the applied coating. ${ }^{21,51,52}$ The impedance of the $\mathrm{CPE}, Z_{\mathrm{CPE}}$, is given as follows:

$$
Z_{\mathrm{CPE}}=\frac{1}{Y_{0}(\mathrm{j} \omega)^{n}},
$$

where $\mathrm{j}$ is the imaginary number, $\omega$ is the characteristic frequency in $\mathrm{rad} \mathrm{s}^{-1}, Y_{0}$ is the CPE magnitude, and the exponent $n$ is related to the uniformity of the electrode-solution interface -1.0 for a completely uniform and homogeneous surface and 0.5 for a porous electrode. The values found for the parameters of the equivalent electrical circuit are shown in Table I.

The parameter values obtained display a low standard deviation (2 repeat spectra) indicating good precision of the impedance spectra. Some noise was, however, observed at low frequencies in the spectra recorded at higher potentials $(+1.35 \mathrm{~V}$ and $+1.40 \mathrm{~V}$ vs $\mathrm{Ag} / \mathrm{AgCl})$; this noise prevented fitting of the lowest frequency points and led to higher standard deviations in the values of $Y_{0, \mathrm{P}}$.

The charge transfer resistance, $R_{\mathrm{ct}}$, decreases with the potential, which is expected since the EIS experiments were performed within the faradaic region of the DSA anode. The low $R_{\mathrm{ct}}$ values are related to the high activity of the DSA anode for chlorine evolution. The double layer capacitance, $Y_{0, \mathrm{dl}}$, is almost independent of potential in the potential range considered, ranging from $4.79 \mathrm{mF} \mathrm{cm}^{-2} \mathrm{~s}^{\mathrm{n}-1}$ to $6.72 \mathrm{mF} \mathrm{cm}^{-2}$ $\mathrm{s}^{n-1}$, in agreement with other authors. ${ }^{21}$ The highest value obtained, $6.72 \mathrm{mF} \mathrm{cm}^{-2} \mathrm{~s}^{n-1}$ at $+1.35 \mathrm{~V}$ vs $\mathrm{Ag} / \mathrm{AgCl}$, should be a consequence of the lower value of the CPE exponent (n-value) obtained at this potential. The values of the double layer capacitance obtained suggest a macroscopically rough coating since, for smooth and compact electrode surfaces, the expected value would be around $60-80 \mu \mathrm{F} \mathrm{cm} \mathrm{cm}^{-2}{ }^{53}$ Values in the $\mathrm{mF} \mathrm{cm} \mathrm{cm}^{-2}$ range have been assigned to the high 
TABLE I. Fitting parameters and standard deviation ( 2 repeat spectra) obtained from the electrochemical impedance spectra at different potentials, data from Figure 6.

\begin{tabular}{lccccc}
\hline \hline$E^{\mathrm{a}} \mathrm{vs} \mathrm{Ag} / \mathrm{AgCl}(\mathrm{V})$ & 1.20 & $1.25^{\mathrm{b}}$ & 1.30 & 1.35 & 1.40 \\
\hline$R_{\mathrm{ct}}{ }^{\mathrm{c}}\left(\Omega \mathrm{cm}^{2}\right)$ & $1.16 \pm 0.01$ & 0.60 & $0.49 \pm 0.01$ & $0.43 \pm 0.01$ & $0.33 \pm 0.02$ \\
$Y_{0, \mathrm{dl}}\left(\mathrm{mF} \mathrm{cm}^{-2} \mathrm{~s}^{\mathrm{n}-1}\right)$ & $5.93 \pm 0.07$ & 5.55 & $5.92 \pm 0.02$ & $6.72 \pm 0.03$ & $4.79 \pm 0.15$ \\
$n^{\mathrm{e}}$ & $0.96 \pm 0.01$ & 0.96 & $0.94 \pm 0.01$ & $0.92 \pm 0.01$ & $0.96 \pm 0.01$ \\
$R_{\mathrm{P}}{ }^{\mathrm{f}}\left(\mathrm{m} \Omega \mathrm{cm}^{2}\right)$ & $4.62 \pm 0.04$ & 0.93 & $0.38 \pm 0.01$ & $0.23 \pm 0.01$ & $0.22 \pm 0.03$ \\
$Y_{0, \mathrm{P}^{\mathrm{g}}}\left(\mathrm{F} \mathrm{cm}^{-2} \mathrm{~s}^{\mathrm{n}-1}\right)$ & $0.028 \pm 0.00$ & 0.32 & $1.59 \pm 0.04$ & $2.57 \pm 0.17$ & $2.24 \pm 0.34$ \\
$n_{\mathrm{p}}{ }^{\mathrm{h}}$ & $0.88 \pm 0.01$ & 0.71 & $0.62 \pm 0.01$ & $0.60 \pm 0.01$ & $0.55 \pm 0.01$ \\
\hline \hline
\end{tabular}

${ }^{\mathrm{a}}$ Applied potential.

${ }^{\mathrm{b}}$ Only one read.

${ }^{\mathrm{c}}$ Charge transfer resistance.

${ }^{\mathrm{d}}$ Magnitude of the double layer CPE.

${ }^{\mathrm{e}}$ Exponent of the double layer CPE.

${ }^{\mathrm{f}}$ Resistance related to the adsorption of intermediates.

${ }^{\mathrm{g}}$ Magnitude of the pseudocapacitance CPE.

${ }^{\mathrm{h}}$ Exponent of pseudocapacitance CPE.

roughness of the electrode surface and, even more important, to the presence of hydrated molecules in the coating. ${ }^{53}$ These features are strongly dependent on the calcination temperature of the electrode coating. ${ }^{53} n$-values smaller than 1.0 can be attributed to the porosity and the roughness of the metal oxide coating that leads to a non-uniform current distribution on the electrode. ${ }^{21,51,52}$ Nevertheless, the values of $n$ close to 1.0, i.e., $0.92-0.96$, show that the microscopic and sub-microscopic roughness of the surface is small. These values are rather different from those reported by Hoseinieh et al. ${ }^{20,21}$ who tested coatings with very similar composition to the ternary metal oxide-composition $\mathrm{IrO}_{2}-\mathrm{TiO}_{2}-\mathrm{RuO}_{2}$ used in this work; these authors found values of $n$ around 0.60 for new anodes and around 0.92 for used electrodes. However, more dilute sodium chloride solutions $(0.5 \mathrm{~mol}$ $\mathrm{dm}^{-3} \mathrm{NaCl}$ ) were used.

Regarding the adsorption/desorption of chloride intermediates, represented by the low frequency semicircle, the low frequency resistance, $R_{\mathrm{p}}$, decreases exponentially with increasing potential. This variation was reported for different electrochemical systems in which the same EEC as here was used $^{11,54,55}$ and confirms the faradaic nature of the adsorption processes. In this work, the value of $C_{\mathrm{p}}$ increased from 0.028 $\mathrm{F} \mathrm{cm}^{-2} \mathrm{~s}^{\mathrm{n}-1}$ at $+1.20 \mathrm{~V}$ vs $\mathrm{Ag} / \mathrm{AgCl}$ to $2.57 \mathrm{~F} \mathrm{~cm}^{-2} \mathrm{~s}^{\mathrm{n}-1}$ at $+1.35 \mathrm{~V}$ vs Ag/AgCl, before decreasing to $2.24 \mathrm{~F} \mathrm{~cm}^{-2} \mathrm{~s}^{\mathrm{n}-1}$ at $+1.40 \mathrm{~V}$ vs $\mathrm{Ag} / \mathrm{AgCl}$. Since $C_{\mathrm{p}}$ is proportional to the variation of the free active sites with potential $d \theta / d E,{ }^{56}$ the maximum observed in $C_{\mathrm{p}}$ corresponds to the maximum

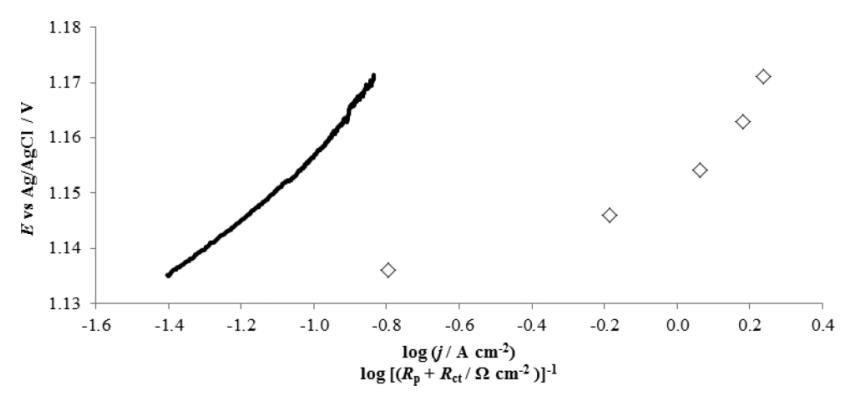

FIG. 8. Polarization curves-closed symbols-vs $E-\log \left(R_{\mathrm{p}}+R_{\mathrm{ct}}\right)^{-1}$-open symbols-for a DSA electrode in $5 \mathrm{~mol} \mathrm{dm}^{-3} \mathrm{NaCl}, \mathrm{pH} 2$ at $60^{\circ} \mathrm{C}$. value of $d \theta / d E$. The CPE exponent at low frequencies, $n_{\mathrm{p}}$, decreases with the applied potential, from a value of 0.88 at $+1.20 \mathrm{~V}$ vs $\mathrm{Ag} / \mathrm{AgCl}$ down to 0.55 at $+1.40 \mathrm{~V}$ vs $\mathrm{Ag} / \mathrm{AgCl}$. This decrease suggests that at higher potentials and higher current densities, the flux of reactants is not sufficient to compensate the depletion of ions on the surface of the pores of the coating, leading to non-uniformity.

\section{E. Polarisation curves vs electrochemical impedance spectroscopy}

Figure 8 shows the high potential region of the polarization curve in Figure 4 corresponding to the potential range in which the impedance spectra were recorded. In addition, in Figure 8 , the potential is represented as $\log \left(R_{\mathrm{p}}+R_{\mathrm{ct}}\right)^{-1}$, with $R_{\mathrm{p}}$ and $R_{\mathrm{ct}}$ obtained from the EIS fitting. In Figure 8 , for the points obtained at higher potentials, the polarization curve and the $E$ vs $\log \left(R_{\mathrm{p}}+R_{\mathrm{ct}}\right)^{-1}$ curve are shown to be parallel. According to Krstajić and coworkers, ${ }^{55}\left(R_{\mathrm{p}}+R_{\mathrm{ct}}\right)$ represents the total faradaic resistance of the electrode, which is the reciprocal of the faradaic current at each potential; therefore, the polarization curve and $E$ vs $\log \left(R_{\mathrm{p}}+R_{\mathrm{ct}}\right)^{-1}$ should be parallel.

\section{CONCLUSIONS}

A new electrochemical cell has been designed, fabricated, and tested for studying the performance of DSA electrodes during chlorine evolution. The cell is able to accommodate electrodes with only one face contacting the electrolyte. The working electrode was fitted to the bottom of the electrochemical cell with a leak-free O-ring seal. This special configuration together with the cell stirring guarantees fast gas removal from the electrode surface during chlorine evolution, leading to high quality impedance spectra and polarization curves. Polarization curves, cyclic voltammetry and impedance measurements demonstrated the good performance of the electrochemical cell over the faradaic regions of the applied potential. EIS measurements were made at different potentials, with current densities up to $140 \mathrm{~mA} \mathrm{~cm}^{-2}$. The EIS and the polarization curves evidence 
the role of adsorption steps in the chlorine evolution reaction, in agreement with the Volmer-Heyrovsky and Volmer-Tafel mechanisms.

The new cell represents an important development for the study and characterization of DSA electrodes under conditions similar to those used in the chlorine industry.

\section{ACKNOWLEDGMENTS}

J. F. Silva thanks Fundação para a Ciência e Tecnologia (FCT) and CUF-Químicos Industriais, S.A., for the cofinanced Ph.D. Grant No. SFRH/BDE/2011/51398.

${ }^{1}$ P. Schmittinger, Chlorine: Principles $\mathcal{E}$ Industrial Practice (Wiley, Weinheim, 2008).

${ }^{2}$ T. O'Brien, T. V. Bommaraju, and F. Hine, Handbook of Chlor-Alkali Technology (Springer, New York, 2005).

${ }^{3}$ T. V. Bommaraju, T. O’Brien, B. Lüke, and M. C. Blackburn, "Chlorine," in Encyclopedia of Chemical Technology Kirk-Othmer, electronic release edited by R. E. Kirk and D. F. Othmer (John Wiley \& Sons, New York, 2002). ${ }^{4}$ P. Schmittinger, T. Florkiewicz, L. C. Curlin, B. Lüke, R. Scannell, T. Navin, E. Zelfel, and R. Bartsch, "Chlorine," in Ullmann's Encyclopedia of Industrial Chemistry, electronic release edited by B. Elvers (Wiley-VCH, Weinheim, 2012).

${ }^{5}$ E. J. Calvo, A. Hamnet, E. J. M. O’Sullivan, and M. J. Weaver, "Electrode kinetics: Reactions," in Comprehensive Chemical Kinetics, edited by R. G. Compton (Elsevier, Amsterdam, 1987).

${ }^{6}$ A. T. Kuhn and C. J. Mortimer, J. Electrochem. Soc. 120, 231 (1973).

${ }^{7}$ L. J. J. Janssen, L. M. C. Starmans, J. G. Visser, and E. Barendrecht, Electrochim. Acta 22, 1093 (1977).

${ }^{8}$ L. I. Krishtalik, Electrochim. Acta 26, 329 (1981).

${ }^{9}$ M. H. P. Santana and L. A. De Faria, Electrochim. Acta 51, 3578 (2006).

${ }^{10}$ R. Boggio, A. Carugati, G. Lodi, and S. Trasatti, J. Appl. Electrochem. 15, 335 (1985).

${ }^{11}$ B. E. Conway and G. Ping, J. Chem. Soc., Faraday Trans. 87, 2705 (1991).

${ }^{12}$ F. B. Li, A. R. Hillman, and S. D. Lubetkin, Electrochim. Acta 37, 2715 (1992).

${ }^{13}$ B. E. Conway and G. Ping, J. Chem. Soc., Faraday Trans. 86, 923 (1990).

${ }^{14}$ V. V. Panić, A. B. Dekanski, M. Mitrić, S. K. Milonjić, V. B. MiškovicStanković, and B. Ž. Nikolić, Phys. Chem. Chem. Phys. 12, 7521 (2010).

${ }^{15}$ X. L. Zhou, Z. G. Ye, X. Z. Hua, A. H. Zou, and Y. H. Dong, J. Solid State Electrochem. 14, 1213 (2010).

${ }^{16}$ V. A. Alves, L. A. da Silva, and J. F. C. Boodts, Electrochim. Acta 44, 1525 (1998).

${ }^{17}$ G. R. P. Malpass, R. S. Neves, and A. J. Motheo, Electrochim. Acta 52, 936 (2006).

${ }^{18}$ V. V. Panić, A. B. Dekanski, V. B. Miškovic-Stanković, S. K. Milonjić, and B. Ž. Nikolić, J. Serb. Chem. Soc. 75, 1413 (2010).

${ }^{19}$ L. K. Xu and J. D. Scantlebury, Corros. Sci. 45, 2729 (2003).

${ }^{20}$ S. M. Hoseinieh and F. Ashrafizadeh, Ionics 19, 113 (2013).

${ }^{21}$ S. M. Hoseinieh, F. Ashrafizadeh, and M. H. Maddahi, J. Electrochem. Soc. 157, E50 (2010).

${ }^{22}$ D. A. Denton, J. A. Harrison, and R. I. Knowles, Electrochim. Acta 24, 521 (1979).

${ }^{23}$ J. A. Harrison, D. L. Caldwell, and R. E. White, Electrochim. Acta 29, 203 (1984).
${ }^{24} \mathrm{P}$. Kissinger and W. R. Heineman, Laboratory Techniques in Electroanalytical Chemistry, revised and expanded, 2nd ed. (Taylor \& Francis, New York, 1996).

${ }^{25}$ N. Watanabe, J. Morais, and M. C. M. Alves, J. Electron Spectrosc. Relat. Phenom. 156-158, 164 (2007).

${ }^{26}$ N. R. Wozniak, A. A. Frey, L. W. Osterbur, T. S. Boman, and J. R. Hampton, Rev. Sci. Instrum. 81, 034102 (2010).

${ }^{27}$ J. Tymoczko, W. Schuhmann, and A. S. Bandarenka, Phys. Chem. Chem. Phys. 15, 12998 (2013)

${ }^{28}$ X. H. Mu and F. A. Schultz, Electroanalysis 2, 353 (1990).

${ }^{29}$ B. D. Cahan, Z. Nagy, and M. A. Genshaw, J. Electrochem. Soc. 119, 64 (1972).

${ }^{30}$ T. Raju and C. A. Basha, Chem. Eng. J. 114, 55 (2005).

${ }^{31}$ C. G. Zoski, Handbook of Electrochemistry (Elsevier, Amsterdam, 2007).

${ }^{32}$ Z. G. Ye, H. M. Meng, and D. B. Sun, J. Electroanal. Chem. 621, 49 (2008).

${ }^{33}$ L. Torcheux, A. Mayeux, and M. Chemla, J. Electrochem. Soc. 142, 2037 (1995).

${ }^{34}$ E. McCafferty, Introduction to Corrosion Science (Springer, New York, 2010).

${ }^{35}$ A. Ghahremaninezhad, E. Asselin, and D. G. Dixon, "Cathodic reactions on oxidized chalcopyrite electrode," in Electrometallurgy, edited by M. Free and M. Moats (John Wiley \& Sons Inc., 2012).

${ }^{36}$ H. Matsushima, T. Iida, and Y. Fukunaka, J. Solid State Electrochem. 16, 617 (2012).

${ }^{37}$ S. Trasatti, Electrochim. Acta 29, 1503 (1984).

${ }^{38}$ L. J. J. Janssen, Electrochim. Acta 23, 81 (1978).

${ }^{39}$ S. Klink, E. Madej, E. Ventosa, A. Lindner, W. Schuhmann, and F. La Mantia, Electrochem. Commun. 22, 120 (2012).

${ }^{40}$ G. J. Offer, P. Shearing, J. I. Golbert, D. J. L. Brett, A. Atkinson, and N. P. Brandon, Electrochim. Acta 53, 7614 (2008).

${ }^{41}$ M. G. Fouad and G. H. Sedahmed, Electrochim. Acta 18, 55 (1973).

${ }^{42}$ R. Ovarfort, Corros. Sci. 28, 135 (1988).

${ }^{43}$ V. Bertagna, F. Rouelle, and M. Chemla, J. Appl. Electrochem. 27, 1179 (1997).

${ }^{44}$ S. A. Hendricks, Y. T. Kim, and A. J. Bard, J. Electrochem. Soc. 139, 2818 (1992).

${ }^{45}$ D. R. Yaniv and P. S. Jung, Electroanalysis 7, 260 (1995).

${ }^{46}$ R. Bowler, T. J. Davies, M. E. Hyde, and R. G. Compton, Anal. Chem. 77, 1916 (2005)

${ }^{47}$ V. Consonni, S. Trasatti, F. Pollak, and W. E. O'Grady, J. Electroanal. Chem. 228, 393 (1987).

${ }^{48}$ B. V. Tilak, C. P. Chen, V. I. Birss, and J. Wang, Can. J. Chem. 75, 1773 (1997).

${ }^{49}$ F. Fathollahi, M. Javanbakht, P. Norouzi, and M. Ganjali, Russ. J. Electrochem. 47, 1281 (2011).

${ }^{50}$ C. M. A. Brett and A. M. Oliveira-Brett, Electrochemistry: Principles, Methods, and Applications (Oxford University Press, Oxford, 1993).

${ }^{51}$ V. A. Alves, L. A. d. Silva, and J. F. C. Boodts, J. Appl. Electrochem. 28 , 899 (1998).

${ }^{52}$ J. Ribeiro and A. R. de Andrade, J. Electroanal. Chem. 592, 153 (2006).

${ }^{53}$ T. A. F. Lassali, J. F. C. Boodts, and L. O. S. Bulhões, Electrochim. Acta 44, 4203 (1999).

${ }^{54}$ N. V. Krstajić, S. Burojević, and L. M. Vračar, Int. J. Hydrogen Energy 25 , 635 (2000).

${ }^{55}$ N. Krstajić, M. Popović, B. Grgur, M. Vojnović, and D. Šepa, J. Electroanal. Chem. 512, 16 (2001).

${ }^{56}$ L. Bai, D. A. Harrington, and B. E. Conway, Electrochim. Acta 32, 1713 (1987). 